\title{
STUDYING THE PROFITABILITY OF THE MINING FARM'S OPERATIONS"
}

\section{Georgii G. VINOGOROV}

Belarus State Economic University,

Minsk, Republic of Belarus

vinahorav-h@yandex.ru

https://orcid.org/0000-0002-2586-0029

\section{Article history:}

Article No. 160/2019

Received 19 Feb 2019

Received in revised form 28 March 2019

Accepted 26 April 2019 Available online

30 March 2021
JEL classification:

cryptocurrency, mining, profitability, mining farm

\begin{abstract}
Subject. The article examines the profitability of the mining farm.

Objectives. I determine what aspects the mining farm's profitability should be analyzed, and articulate my own technique for analyzing, untapping the room for the profitability growth on the analyzable mining farm.

Methods. To make my suggestions reasonable, reliable and substantiate them, I use the comprehensive approach to studying the profitability of the mining farm, general and special methods of research, such as the retrospective, systems and functional-structural analysis, observation, classification, instrumental techniques for grouping, sampling, comparison and generalization, factor analysis.

Results. The study is the first to present the structural-logic model of the factor system of profitability of the mining farm. I assessed factors that influenced the profitability, found bottle necks and aspects to focus on in order to improve the performance of the mining farm.

Conclusions and Relevance. Business entities that are residents at the Belarus Part of High Technology and have mining farms can use the proposed technique, which are of applied nature.
\end{abstract}

(c) Publishing house FINANCE and CREDIT, 2019

Please cite this article as: Vinogorov G.G. Studying the Profitability of the Mining Farm's Operations. Digest Finance, 2021, vol. 26, iss. 1, pp. 44 - 52.

https://doi.org/10.24891/df.26.1.44

Decree of the President of the Republic of Belarus, On the Development of the Digital Economy $^{1}$ (hereinafter referred to as Decree No. 8) came into effect on March 28, 2018 and gave a strong impetus to the development of residents at the Park of High Technology. Almost 50 percent of them acquired the status in 2018. The regulatory document seriously made Belarus more lucrative for investors and contributed to the digitalization of the Belarussian economy. In the Russian Federation, the national government drafted the federal law, On Digital Financial Assets ${ }^{2}$. The digital economy

\footnotetext{
" For source article please refer to: Виногоров Г.Г. Анализ рентабельности работы майнинг-фермы // Экономический анализ: теория и практика. 2019. Т. 18. № 7. С. 1322-1331.

URL: https://doi.org/10.24891/ea.18.7.1322

${ }^{1}$ O развитии цифровой экономики: Декрет Президента Республики Беларусь от 21.12.2017 № 8. URL: http:// president.gov.by/ru/official_documents_ru/view/dekret-8-ot-21-dekabrja-2017-g-17716/

${ }^{2} \mathrm{O}$ цифровых финансовых активах: проект федерального закона Российской Федерации. URL: https://www.minfin.ru/ru/document/?id_4=121810
} 
brings innovation, thriving by implementing advanced information technology. Decree No. 8 introduced new concepts into the business process, such as cryptocurrency, blockchain, mining, token, bitcoin, etc.

There is no country across the entire post-Soviet area, where the governmental issue of bank-notes could be coupled with the private one. Decree No. 8 laid the basis for doing so, albeit some limitations.

It was the first attempt to develop a technique for analyzing the profitability of a mining farm.

Cryptocurrency is an internal payment unit of any public blockchain, i.e. blockchain based on $\mathrm{P}-\mathrm{O}-\mathrm{W}$ or $\mathrm{P}-\mathrm{O}-\mathrm{S}$ mining. Mining is a crucial and inevitable process of the public blockchain, where cryptocurrency stimulates miners. Furthermore, cryptocurrency serves for transaction fees. It can be sold (exchanged for fiat money).

Therefore, cryptocurrency works as:

- a payment means (unit of value) in the blockchain;

- an incentive for miners;

- a means of exchange for the value (transactions);

- storage of the value.

Cryptocurrency is created first and then distributed among its holders. As per Decree No. 8, holders are agents of the civil law, both individuals and special business entities, which free-hold a digital mark (token) or hold it under other property right. Tokens, which are functional equivalent of cash money issue, are not given as a result of a purchase or any other property deal, but rather a solution to mathematical risks, compensation for the verification of blockchain operations. Therefore, mining is a process of acquiring new cryptocurrency units, with profit being its main purpose [1-18].

I can hardly refer to any sources of business analysis literature, which would focus on aspects I analyze herein. Based on the above concepts, I would measure the cost effectiveness of a mining farm through the profitability:

$P_{M}=\frac{\text { Profit }}{C(M)} \cdot 100$

where $P_{\mathrm{m}}$ is the profitability of mining;

Profit is profit from the sale of cryptocurrency;

$C(M)$ stands for costs incurred for mining. 
The reduced cost can be expressed as a combination of costs incurred for power supply, depreciation on equipment, repair of equipment, principal and additional salaries, taxes, budgetary and extra-budgetary charges, charges to local authorities.

Hence, the profitability of mining can be expressed as follows:

$$
\begin{aligned}
& P_{M}=\frac{\text { Profit }}{M}= \\
& =\frac{S P_{C r p t}-\left(E+D_{E q p t}+R_{E q p t}+S_{\text {Prin }}+S_{\text {Add }}+T\right)}{E+D_{\text {Eqpt }}+R_{E q p t}+S_{\text {Prin }}+S_{\text {Add }}+T} 100,
\end{aligned}
$$

where $S P_{C r p t}$ is the selling price for cryptocurrency sold, net of taxes and payments made from revenue;

$E$ means power supply costs;

$D_{\text {Eqpt }}$ means the depreciation on equipment;

$R_{\text {Eqpt }}$ means costs for the repair of equipment;

$S_{\text {Prin }}$ means the principal salary;

$S_{\text {Add }}$ means the additional salary;

$T$ means taxes, budgetary and extra-budgetary charges, charges to local authorities.

Having this in mind, I devised the first structural-logical model of the factor-based profitability of the mining farm's operations (Fig. 1).

So, we get a multiple type of the factor-based system. To assess the impact of the factors, I use the chain substitution method. Table 1 shows a range of the indicators.

The impact of the factors is assessed as follows:

$$
\begin{aligned}
& \text { Profit }^{\mathrm{I}}-\text { Profit }_{0}=\Delta \text { Profit }_{S P_{\mathrm{Cr} i t}} ; \\
& \text { Profit }^{\mathrm{II}}-\text { Profit }^{\mathrm{I}}=\Delta \text { Profit }_{E} ; \\
& \text { Profit }^{\mathrm{III}}-\text { Profit }^{\mathrm{II}}=\Delta \text { Profit }_{D_{\mathrm{Eqpp}} ;} \\
& \text { Profit }^{\mathrm{IV}}-\text { Profit }^{\mathrm{III}}=\Delta \text { Profit }_{\mathrm{E}_{\mathrm{Eqp}}} ; \\
& \text { Profit }^{\mathrm{V}}-\text { Profit }^{\mathrm{V}}=\Delta \text { Profit }_{\text {Prrin }} ; \\
& \text { Profit }^{\mathrm{VI}}-\text { Profit }^{\mathrm{V}}=\Delta \text { Profit }_{S_{\text {Add }}} ; \\
& \text { Profit }_{1}-\text { Profit }^{\mathrm{VI}}=\Delta \text { Profit }_{T} ; \\
& \text { Profit }_{1}-\text { Profit }_{0}=\Delta \text { Profit }
\end{aligned}
$$


Table 2 contain available data on the analyzable mining farm. As the data show, RUB 16.8 thousand was saved for the reporting period, that is 2.6 percent of the target amount. Costs for the repair of equipment increased by RUB 12 thousand, or 30 percent. This is due to the fact that the expensive equipment broke down unexpectedly, thereby hampering the mining process for some time. Electricity was not consumed, so saving RUB 22 thousand, or 4.23 percent of the target amount. There were some vacant positions on the staff for some period of time, thus economizing RUB 6 thousand in salaries, that is 12.5 percent of the budget.

The selling price for cryptocurrency sold (provided general costs and expenditures for distribution are directly posted to Account 90-5 Income and Expenses for Current Operations - Administrative Expenses and Account 90-6 Income and Expenses for Current Operations - Selling Expenses respectively) was planned to be about RUB 740.6 thousand, while the factual selling price turned to be RUB 784 thousand.

Table 3 presents indices for analyzing the profitability of the mining farm. Table 4 helps assess factors that influenced the profitability.

Table 4 clearly illustrates the extent to which all the factors have an impact and their structure. As the assessment proves, a growth of the selling price for the cryptocurrency sold by RUB 43.4 thousand was proved to have the greatest effect on the profitability of the mining farm, which resulted in 6.74-percent growth in profitability, or 67.4 percent of changes in the resultant index. As electricity bills reduced by RUB 22 thousand, the profitability grew by 4.36 percent, or 43.6 percent of total changes in the resultant index. In the mean time, as the repair of equipment now cost by RUB 12 thousand more, the profitability dropped by 2.44 percent, or 24.4 percent of changes in the resultant index. The preventative maintenance of the functioning equipment should be scheduled appropriately.

I herein presented the technique for studying the profitability of the mining farm and devised the structural-logic model of the factor-based system of the mining farm's profitability.

The use of the technique will help businesses residing in the Belarusian Part of High Technology and having mining farms promptly locate bottlenecks in the mining process and make appropriate administrative decisions, if needed. The technique will be helpful for respective business entities of the Russian Federation and other EEU countries to adopt corresponding regulations and put them into practice. 


\section{Table 1}

\section{Levels of indicators}

\begin{tabular}{llllllll}
\hline Profitability Level & $\boldsymbol{S P}_{\text {rrpt }}$ & $\boldsymbol{E}$ & $\boldsymbol{D}_{\text {Eqpt }}$ & $\boldsymbol{R}_{\text {Eqpt }}$ & $\boldsymbol{S}_{\text {Prin }}$ & $\boldsymbol{S}_{\text {Add }}$ & $\boldsymbol{T}$ \\
\hline $\begin{array}{l}\text { Plan (baseline) } \\
P_{0}\end{array}$ & Plan & Plan & Plan & Plan & Plan & Plan & Plan \\
\hline $\begin{array}{l}\text { Substitution 1 } \\
P^{\mathrm{I}}\end{array}$ & Fact & Plan & Plan & Plan & Plan & Plan & Plan \\
\hline $\begin{array}{l}\text { Substitution 2 } \\
P^{\mathrm{II}}\end{array}$ & Fact & Fact & Plan & Plan & Plan & Plan & Plan \\
\hline $\begin{array}{l}\text { Substitution 3 } \\
P^{\mathrm{III}}\end{array}$ & Fact & Fact & Fact & Plan & Plan & Plan & Plan \\
\hline $\begin{array}{l}\text { Substitution 4 } \\
P^{\mathrm{IV}}\end{array}$ & Fact & Fact & Fact & Fact & Plan & Plan & Plan \\
\hline $\begin{array}{l}\text { Substitution 5 } \\
P^{\mathrm{V}}\end{array}$ & Fact & Fact & Fact & Fact & Fact & Plan & Plan \\
\hline $\begin{array}{l}\text { Substitution 6 } \\
P^{\mathrm{VI}}\end{array}$ & Fact & Fact & Fact & Fact & Fact & Fact & Plan \\
\hline $\begin{array}{l}\text { Fact } \\
P_{1}\end{array}$ & Fact & Fact & Fact & Fact & Fact & Fact & Fact
\end{tabular}

Note. "Fact" is the factual indicator; "Plan" is the planned indicator.

Source: Authoring

Table 2

Data to analyze the cost-effectiveness of mining, thousand RUB

\begin{tabular}{llll}
\hline Cost Item & Plan & Fact & Variance \\
\hline Electricity costs & 520 & 498 & -22 \\
\hline Depreciation on equipment & 24 & 24 & - \\
\hline Equipment repair costs & 40 & 52 & 12 \\
\hline Principal salary & 48 & 42 & -6 \\
\hline Additional salary & 1 & 1 & -1 \\
\hline $\begin{array}{l}\text { Taxes, budgetary and extra-budgetary charges, } \\
\text { charges to local authorities }\end{array}$ & 11 & 10.2 & -0.8 \\
\hline Total & $\mathbf{6 4 4}$ & $\mathbf{6 2 7 . 2}$ & $\mathbf{- 1 6 . 8}$
\end{tabular}

Source: Authoring 


\section{Table 3}

Indicators for an analysis of the mining farm profitability

\begin{tabular}{lll}
\hline Indicator & Computation & Profitability, \% \\
\hline Plan (baseline) & $\frac{740.6-644}{644} 100$ & 15 \\
\hline $\begin{array}{l}\text { As planned given the factual selling price } \\
\text { for cryptocurrency sold }\end{array}$ & $\frac{784-644}{644} 100$ & 21.74 \\
\hline $\begin{array}{l}\text { As planned given the factual selling price } \\
\text { of cryptocurrency sold and electricity costs }\end{array}$ & $\frac{784-(498+24+40+48+1+11)}{498+24+40+48+1+11} 100$ & 26.1 \\
\hline $\begin{array}{l}\text { As planned given the factual selling price } \\
\text { for cryptocurrency sold, electricity costs and } \\
\text { depreciation on equipment }\end{array}$ & $\frac{784-(498+24+40+48+1+11)}{498+24+40+48+1+11} 26.1$ & \\
\hline $\begin{array}{l}\text { As planned given the factual selling price } \\
\text { for cryptocurrency sold, electricity costs, } \\
\text { depreciation and repair of equipment }\end{array}$ & $\frac{784-(498+24+52+48+1+11)}{498+24+52+48+1+11} 100$ & 23.66 \\
\hline $\begin{array}{l}\text { As planned given the factual selling price } \\
\text { for cryptocurrency sold, electricity costs, } \\
\text { depreciation and repair of equipment, } \\
\text { and the principal salary }\end{array}$ & $\frac{784-(498+24+52+42+1+11)}{498+24+52+42+1+11} 100$ & 24.84 \\
\hline $\begin{array}{l}\text { As planned given the factual selling price } \\
\text { for cryptocurrency sold, electricity costs, } \\
\text { depreciation and repair of equipment, } \\
\text { the principal and additional salary }\end{array}$ & $\frac{784-(498+24+52+42+1+11)}{498+24+52+42+1+11} 100$ & 24.84 \\
\hline $\begin{array}{l}\text { Fact } \\
\text { Pat }\end{array}$ & $\frac{784-627.2}{627} 100$ & \\
\hline
\end{tabular}

Source: Authoring 


\section{Table 4}

Calculation of factors affecting the changes in mining farm profitability

\begin{tabular}{llll}
\hline Factor & $\begin{array}{l}\text { Impact } \\
\text { Assessment }\end{array}$ & $\begin{array}{l}\text { Impact } \\
\text { Assessment, \% }\end{array}$ & $\begin{array}{l}\text { Structure of } \\
\text { factors, \% }\end{array}$ \\
\hline Changes in the selling price for cryptocurrency sold & $21.74-15$ & 6.74 & 67.4 \\
\hline Changes in electricity costs & $26.1-21.74$ & 4.36 & 43.6 \\
\hline Changes in equipment depreciation costs & $26.1-26.1$ & 0 & - \\
\hline Changes in equipment repair costs & $23.66-26.1$ & -2.44 & -24.4 \\
\hline Changes in the principal payroll costs & $24.84-23.66$ & 1.18 & 11.8 \\
\hline Changes in the additional salary costs & $24.84-24.84$ & 0 & - \\
\hline $\begin{array}{l}\text { Changes in tax expenditures, budgetary and } \\
\text { extrabudgetary charges, charges to local authorities }\end{array}$ & $25-24.84$ & 0.16 & 1.6 \\
\hline Total & $\mathbf{2 5 - 1 5}$ & $\mathbf{1 0}$ & $\mathbf{1 0 0}$ \\
\hline
\end{tabular}

Source: Authoring

Figure 1

Structural and logical model of the factor system of the mining farm profitability

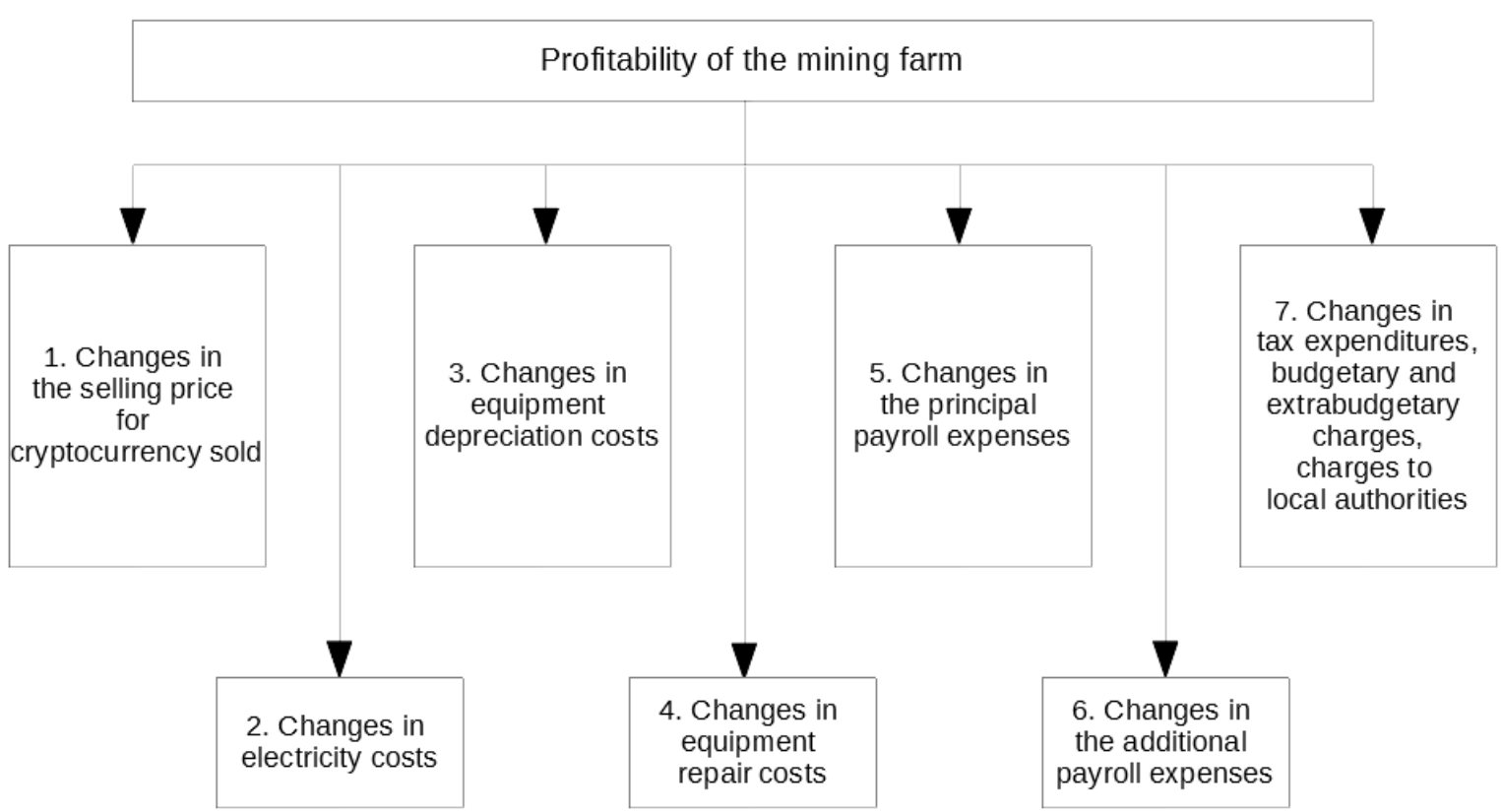

Source: Authoring

\section{References}

1. Butenko E.D., Isakhaev N.R. [Electronic money and cryptocurrencies: Contradictions and traps]. Natsional'nye interesy: prioritety i bezopasnost' = National Interests:

Priorities and Security, 2018, vol. 14, iss. 6, pp. 1092-1108. (In Russ.)

URL: https://doi.org/10.24891/ni.14.6.1092

2. Kuznetsova L.G. [P2P cryptocurrency: Security or development]. Finansy $i$ kredit $=$ Finance and Credit, 2017, vol. 23, iss. 47, pp. 2810-2822. (In Russ.)

URL: https://doi.org/10.24891/fc.23.47.2810 
3. Levi D.A. [Prospects of Recognition and Development of Cryptocurrencies in the European Union and the Countries of Europe]. Upravlencheskoe konsul'tirovanie = Administrative Consulting, 2016, no. 9, pp. 148-158.

URL: https://cyberleninka.ru/article/n/perspektivy-priznaniya-i-razvitiya-kriptovalyutv-evropeyskom-soyuze-i-stranah-evropy (In Russ.)

4. Nikolaichuk O.A. [Electronic currency in the light of modern legal and economic challenges]. Journal of Economic Regulation, 2017, vol. 8, no. 1, pp. 142-154. URL: https://cyberleninka.ru/article/n/elektronnaya-valyuta-v-svete-sovremennyhpravovyh-i-ekonomicheskih-vyzovov (In Russ.)

5. Omel'chenko E.Yu. [A conflict of interests when using crypto-currency: The realities of modernity, accounting and control]. Transportnoe delo Rossii = Transport Business in Russia, 2017, no. 2, pp. 70-72. URL: https://cyberleninka.ru/article/n/konfliktinteresov-pri-ispolzovanii-kriptovalyut-realii-sovremennosti-uchet-i-kontrol (In Russ.)

6. Rasheva N.Yu., Chirkova O.I. [Theoretical and legal foundations of e-currency (Bitcoin on the example)]. Upravlenie v sovremennykh sistemakh, 2017, no. 1, pp. 60-68. (In Russ.) URL: https://cyberleninka.ru/article/n/pravovye-osnovyelektronnoy-valyuty-na-primere-bitcoin

7. Stepanova D.I., Nikolaeva T.E., Ivolgina N.V. [Specifics of organization and development of cryptocurrency payment systems]. Finansy $i$ kredit $=$ Finance and Credit, 2016, no. 10, pp. 33-45. URL: https://cyberleninka.ru/article/n/osobennostiorganizatsii-i-napravleniya-razvitiya-kriptovalyutnyh-platezhnyh-sistem (In Russ.)

8. Fetisov V.D., Fetisova T.V. [Issues of Bitcoin use and economic security]. Natsional'nye interesy: prioritety i bezopasnost' $=$ National Interests: Priorities and Security, 2018, vol. 14, iss. 3, pp. 452-464. (In Russ.)

URL: https://doi.org/10.24891/ni.14.3.452

9. Shcherbik E.E. [The phenomenon of cryptocurrency: System description experience]. Kontsept, 2017, no. S1. (In Russ.) URL: https://e-koncept.ru/2017/470010.htm

10. Bouoiyour J., Selmi R. Bitcoin price: Is it really that new round of volatility can be on way? MPRA Paper, 2015, no. 65580.

URL: https://mpra.ub.uni-muenchen.de/65580/1/MPRA_paper_65580.pdf

11. Kucherov I.I., Khavanova I.A. [Tax Consequences of Using Alternative Means of Payment (Theoretical and Legal Aspects)]. Vestnik Permskogo universiteta. Yuridicheskie nauki $=$ Perm University Herald. Juridical Sciences, 2017, no. 35, pp. 66-72. URL: https://cyberleninka.ru/article/n/nalogovye-posledstviyaispolzovaniya-alternativnyhplatezhnyh-sredstv-teoretiko-pravovye-aspekty (In Russ.) 
12. Kudryashova E.V. [Cryptocurrency within the legal framework]. Finansy $i$ kredit $=$ Finance and Credit, 2018, vol. 24, iss. 10, pp. 2175-2183. (In Russ.)

URL: https://doi.org/10.24891/fc.24.10.2175

13. White L.H. The market for Cryptocurrencies. Cato Journal, 2015, vol. 35, iss. 2, pp. 383-402. URL: https://object.cato.org/sites/cato.org/files/serials/files/cato-journal/ 2015/5/cj-v35n2-13.pdf

14. Yermack D. Is a Bitcoin a Real Currency? An Economic Appraisal. NBER Working Paper, 2013, no. 19747. URL: http://www.nber.org/papers/w19747.pdf

15. Batoev V.B., Semenchuk V.V. [How to Overcome Problems in Combating Criminal Use of Virtual Cryptocurrencies]. Trudy Akademii upravleniya MVD Rossii = Proceedings of Management Academy of the Ministry of the Interior of Russia, 2017, no. 2, pp. 9-15. URL: https://cyberleninka.ru/article/n/ispolzovanie-kriptovalyuty-vprestupnoy-deyatelnosti-problemy-protivodeystviya (In Russ.)

16. Kuznetsov V.A., Yakubov A.V. [On Approaches to International Regulation of Cryptocurrencies (Bitcoin) in Certain Foreign Jurisdictions]. Den'gi $i$ kredit $=$ Russian Journal of Money and Finance, 2016, no. 3, pp. 20-29.

URL: https://www.cbr.ru/content/document/file/26541/kuznetcov_03_16.pdf (In Russ.)

17. Sal'nikov E.V., Sal'nikova I.N. [The cryptocurrency as an innovation of the economy of terror]. Naukovedenie, 2016, vol. 8, no. 3. (In Russ.)

URL: https://naukovedenie.ru/PDF/86EVN316.pdf

18. Swan M. Blokchein. Skhema novoi ekonomiki [Blockchain: Blueprint for a New Economy]. Moscow, Olimp-Biznes Publ., 2017, 240 p.

\section{Conflict-of-interest notification}

I, the author of this article, bindingly and explicitly declare of the partial and total lack of actual or potential conflict of interest with any other third party whatsoever, which may arise as a result of the publication of this article. This statement relates to the study, data collection and interpretation, writing and preparation of the article, and the decision to submit the manuscript for publication. 